\title{
The sensitivity of white clover root hairs to aluminium
}

\author{
D.A. CARE \\ AgResearch Ruakura, Private Bag 3123, Hamilton, New Zealand
}

\begin{abstract}
Two populations of white clover, selected for long (L) and short (S) root hairs from the cultivar Tamar, were used to determine the root hair response curve to a range of aluminium $(\mathrm{Al})$ concentrations similar to those found under field conditions. Seeds from the $\mathrm{L}$ and $\mathrm{S}$ populations were germinated and grown in low ionic strength hydroponic culture. Al was added to give final concentrations of $0,2.5,5,7.5$ and $10 \mu \mathrm{M} \mathrm{Al}$ in solution. After 4 weeks plants were harvested and subsampled for root hair analysis. Mean root hair length, root hair number and total root hair length were recorded. Mean root hair length decreased by about $30 \%$ at $2.5 \mu \mathrm{M} \mathrm{Al}$, and by $70 \%$ at $10 \mu \mathrm{M} \mathrm{Al}$, but the most $\mathrm{Al}$ sensitive parameter was root hair number. Root hair numbers decreased by $70 \%$ at only $2.5 \mu \mathrm{M} \mathrm{Al}$, and at $10 \mu \mathrm{M} \mathrm{Al}$, had decreased by $99 \%$. This pruning effect on total root hair length and number has major implications for the root hair functions of nutrient acquisition, preserving the moisture film, anchorage and nodulation. These are discussed in relation to New Zealand pastoral systems.
\end{abstract}

Keywords: aluminium tolerance, nodulation, root hairs, root pulling, Trifolium repens L., white clover

\section{Introduction}

Many pasture soils in New Zealand are considered acid (Parfitt \& McDonald 1992), which causes plant growth to be inhibited by elevated levels of soluble aluminium (Al). Relative root length (root length at $\mathrm{X} \mu \mathrm{M} \mathrm{Al}$ as a function of root length at $0 \mu \mathrm{M} \mathrm{Al}$ ) has been used as a selection criterion for $\mathrm{Al}$ tolerance in a range of species (Blamey et al. 1992; Carver \& Ownby 1995). Total root surface area is greatly enhanced by the presence of root hairs, but root hairs are not usually included in estimations of root length or surface area.

Nutrient uptake may be enhanced by the presence of longer root hairs (Itoh \& Barber 1983), particularly for nutrients (e.g. P) that move to the root surface by diffusion. Recent research has demonstrated uptake of Ca by root hair tips, and $\mathrm{K}$ over the entire length of the root hair (Jones et al. 1995). Thus root hair length, and number of root hairs, are important in nutrient acquisition by plants.
Mackay and Barber (1985) demonstrated that the number and length of root hairs increased as soil moisture decreased pointing to the importance of root hairs in maintaining a continuous water film for the movement of nutrients to the root surface. They showed that root hairs were produced to fill soil voids as a soil dried, an important function in maintaining nutrient supply to the root from the soil.

Root hairs are vital for nodulation and nitrogen fixation as they are the infection site for Rhizobium (Nutman 1959). Decreased root hair numbers may limit the nodulation capacity of clover. Root hairs also have an important anchoring function (Hofer 1991). In a pasture situation where grazing animals exert shear stress on the whole plant, an increased number of root hairs may prevent the root being pulled from the ground.

Previous research has shown that at a level of $10 \mu \mathrm{M}$ $\mathrm{Al}$, root hair length and number in white clover decreased by $70 \%$ and $50 \%$ respectively, and at $20 \mu \mathrm{M} \mathrm{Al}$ root hairs were absent (Care 1995). The objective of the current work was to determine a response curve for root hair growth over a lower range of $\mathrm{Al}$ concentrations that may occur in the field.

\section{Materials and methods}

\section{Culture system}

Plants were grown in a temperature controlled glasshouse (minimum $14^{\circ} \mathrm{C}$, maximum $25^{\circ} \mathrm{C}$ ) using low ionic strength solution culture (Blamey et al. 1991). The culture solution has osmotic and chemical properties similar to those which occur in New Zealand field soils (Edmeades et al. 1985). Al was added after 7 days to give final solution concentrations of $0,2.5,5,7.5$ and $10 \mu \mathrm{M} \mathrm{Al}$.

Solutions were completely renewed fortnightly, but were monitored and adjusted daily for $\mathrm{pH}$, thrice weekly for $\mathrm{P}$, and weekly for the other cations and anions. Solution $\mathrm{P}$ concentrations were determined using a modified malachite green method (Motomizu et al. 1983) and maintained by the addition of $\mathrm{NH}_{4} \mathrm{H}_{2} \mathrm{PO}_{4}$. Mineral nitrogen $(\mathrm{N})$ was supplied so that plants were not reliant on fixed N. Other cations and anions were determined by inductively coupled plasma spectrometry (ICPAES) and maintained by the addition of stock solutions. The solution was aerated to ensure good mixing of the solution and oxygenation of the plant roots. 


\section{Plant culture}

Seeds from two lines of white clover cv. Tamar, previously selected for long (L) and short (S) root hair length (Caradus 1979) were scarified and germinated on moistened filter paper. After the cotyledons had emerged, the seedlings were transferred to low ionic strength nutrient solution. Each Al treatment was replicated three times, with white clover lines randomised within $\mathrm{Al}$ treatments.

Plants were grown for 7 days before $\mathrm{Al}$ treatments were imposed. After a further 21 days growth the plants were harvested, divided into roots and shoots, and the shoots were dried and weighed. The roots were placed in a film of water and a $1 \mathrm{~cm}$ band was cut across the middle of the root system. Ten $1 \mathrm{~cm}$ root pieces were taken for root hair analysis. After root hair analysis the entire root system was dried and weighed.

\section{Root hair analysis}

The root segments were placed in a film of water in a microscope slide with raised sides. Root hair images were obtained using a video camera fitted to a microscope interfaced with a computer image grabber board. The microscope was focused on one end of the root segment at 200x magnification and the image displayed live on the computer screen. This image was adjusted to give maximum contrast, then captured and written to disc. The root sample was moved using the mechanical stage, so that the entire segment was captured and the entire root sample written to disc.

Root hair measurements were made by recalling an image using $\mathrm{MD}^{\mathrm{TM}} \mathrm{T}^{\mathrm{TM}}$ software and individual root hairs were selected and highlighted, using an 'anchor and drop' process on the individual root hairs with the computer mouse. All root hairs visible on each screen were counted. Mean, maximum and minimum values were recorded, and frequency histograms of different size class ranges were calculated.

The data was analysed by ANOVA, and treatment effects were determined by rank analyses because of non-homogeneity of the variances. Raw data means are quoted with SEDs calculated from the rank analyses. All statistical analyses were performed using the Genstat statistical package (Numerical Algorithms Group Ltd., Oxford, England).

\section{Results}

\section{The effect of aluminium}

Al significantly $(\mathrm{P}<0.001)$ decreased root hair length, number and total root hair length per $\mathrm{cm}$ of root (Table 1). The largest relative decrease for all root hair parameters occurred with the addition of $2.5 \mu \mathrm{M} \mathrm{Al}$.
The magnitude of the decrease in root hair number, and total root hair length/cm was much larger $(33 \%$ and $24 \%$ of the $0 \mu \mathrm{M} \mathrm{Al}$ treatment, respectively) than that of average root hair length (71\%). At $10 \mu \mathrm{M} \mathrm{Al}$ mean root hair length was $35 \%$ of its value at $0 \mu \mathrm{M} \mathrm{Al}$, whereas root hair number and total root hair length $/ \mathrm{cm}$ were only $1 \%$ and $0.5 \%$ of their $0 \mu \mathrm{M} \mathrm{Al}$ value.

At $10 \mu \mathrm{M} \mathrm{Al}$, root and shoot dry weights decreased significantly $(\mathrm{P}<0.05)$ to $27 \%$ and $35 \%$ respectively, of the $0 \mu \mathrm{M}$ Al values.

Table 1: The effect of $5 \mathrm{Al}$ concentrations ranging from 0 to $10 \mu \mathrm{M} \mathrm{Al}$ on mean root hair length, total root hair count and total root hair length $(\mathrm{mm} / \mathrm{cm})$ of root, for the long $(\mathrm{L})$ and short $(\mathrm{S})$ root hair selections of white clover. (Values are raw means of 3 replicates of the $\mathrm{L}$ and $\mathrm{S}$ plants.)

\begin{tabular}{lcccccc}
\hline & ---- & Aluminium Concentration $\mu \mathrm{M}$ & ---- \\
Root Hair Character & 0 & 2.5 & 5 & 7.5 & 10 & $\mathrm{P}$ \\
\hline Root hair length $(\mu)$ & 112 & 79 & 77 & 48 & 39 & 0.001 \\
$\begin{array}{l}\text { Root hair count } \\
\quad \text { (number/cm) }\end{array}$ & 792 & 266 & 185 & 38 & 8 & 0.001 \\
$\begin{array}{c}\text { Total length of root hairs } \\
\text { (mm/cm of root) }\end{array}$ & 8872 & 2144 & 1393 & 192 & 38 & 0.001 \\
\hline
\end{tabular}

The frequency plot (Figure 1) shows the depression of root hair numbers with increasing $\mathrm{Al}$ concentration and the decreased root hair length especially in the $>200 \mu$ range. Notably, although the frequency peak is markedly decreased by $\mathrm{Al}$, it still occurs in the 50 $100 \mu$ size class until the $\mathrm{Al}$ concentration exceeds $5 \mu \mathrm{M}$ $\mathrm{Al}$, when it peaks in the $0-50 \mu$ size class.

\section{Comparison of white clover lines}

The difference in mean root hair length between the $\mathrm{L}$ and $S$ lines was $11 \mu$ (65 and $76 \mu$ for the $S$ and $L$ lines respectively) which was significant at the $10 \%$ level (Table 2). There was no significant difference in root hair number between the lines (mean value 2574). There was a significant difference $(\mathrm{P}<0.05)$ between the $\mathrm{L}$ and $\mathrm{S}$ lines for total root hair length (Table 2).

Table 2: Mean root hair characteristics of the long (L) and short (S) root hair selections of white clover. (Values are raw means of 3 replicates of the $\mathrm{L}$ and $\mathrm{S}$ plants averaged over all $\mathrm{Al}$ solution concentrations.)

\begin{tabular}{lccc}
\hline Root Hair Character & Short & $\begin{array}{c}\text { Population } \\
\text { Long }\end{array}$ & P \\
\hline $\begin{array}{l}\text { Root hair length }(\mu) \\
\begin{array}{l}\text { Total length of root hairs } \\
(\mathrm{mm} / \mathrm{cm} \text { of root) }\end{array}\end{array}$ & 65 & 76 & 0.1 \\
\hline
\end{tabular}


Figure 1: The effect of $\mathrm{Al}$ concentration $(\mu \mathrm{M})$ on the frequency distribution of root hair length in white clover (Trifolium repens 1.$)$

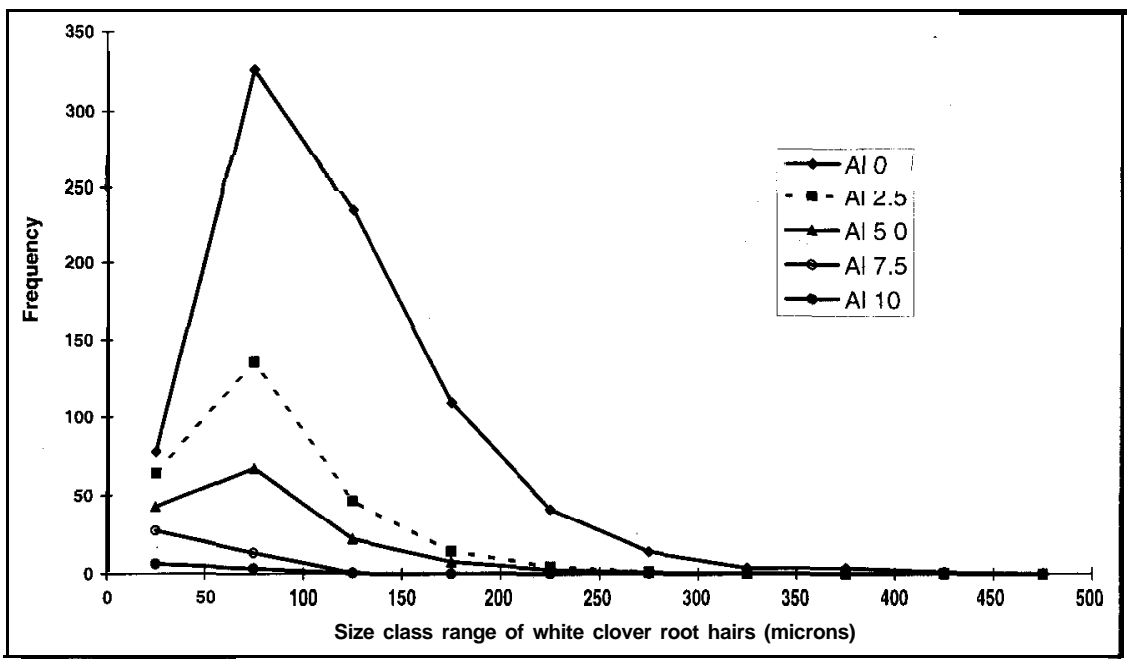

\section{Discussion}

The decrease in root hair number and total length is effectively pruning the potential root system available for anchorage, maintaining a water film and nutrient uptake. At low Al concentrations, mean root hair length was relatively less affected than root hair number and total length of root hairs. The absorption of elements such as K, which are taken up over the entire root hair surface, would be relatively less affected compared to elements such as $\mathrm{Ca}$, where absorption occurs at the root hair tip only (Jones et al.1995), and nutrients that move to the root surface by diffusion. Water uptake would also be affected by the decrease in root hair length. Although there were no significant line $\mathrm{x} \mathrm{Al}$ interactions, the $\mathrm{L}$ line mean root hair length was longer than the $\mathrm{S}$ line in all $\mathrm{Al}$ treatments, which when translated into total root hair length per $\mathrm{cm}$, meant there would be more root surface area available for uptake by the $\mathrm{L}$ line.

Frequency distribution of root hair length suggests that at low levels of $\mathrm{Al}(2.5$ and $5 \mu \mathrm{M} \mathrm{Al})$, root hair growth (i.e. increasing length) still occurred, but at a considerably lower rate than at $0 \mu \mathrm{M}$ Al. With the imposition of 7.5 and $10 \mu \mathrm{M} \mathrm{Al}$ root hair length decreased, indicative of root hair death, and no growth.

The decrease in root hair number shown is this work occurred at a very low concentration of Al. The $\mathrm{Al}^{3+}$ (phytotoxic $\mathrm{Al}$ ) activity was estimated at approximately $0.5-1 \mu \mathrm{M} \mathrm{Al}$ in the $2.5 \mu \mathrm{M} \mathrm{Al}$ treatment. The level of plant toxic $\mathrm{Al}$ is difficult to measure in soil, but recent research on a Horotiu soil in the Waikato, with soil at $\mathrm{pH} 5.8$, had Al levels of 3-33 $\mu \mathrm{M}$. Depending on the concentration of short chain organic acids present, this would equate to an $\mathrm{Al}^{3+}$ activity of $0.6-6 \mu \mathrm{M} A 1$ (Wheeler \& Edmeades 1995). Therefore microsite concentrations of $\mathrm{Al}$ could reach the low activity levels used in this experiment and result in disruption of root function.

Al tolerance research in New Zealand has focussed on hill country, where liming and fertiliser applications have been lower than in dairy type pastures. Al comprises from 1-30 \% of the soil (Wolt 1994) and on improved pastures regular additions of super phosphate fertiliser, which containing 0.3\% Al (During 1972), are common, so that pastures with $\mathrm{pH}<6$ may have low levels of phytotoxic Al present. Pasture pulling is a common phenomenon in dairy pastures, occurring to both white clover and perennial ryegrass. Perennial ryegrass is also sensitive to $\mathrm{Al}$ (Wheeler et al. 1992) but the effect of $\mathrm{Al}$ on ryegrass root hairs is not known. The large decrease in root hair numbers demonstrated here for white clover, at very low $\mathrm{Al}$ levels, provides a possible explanation for root pulling in pasture systems.

Root hairs are implicated in the nitrogen fixation process being a common site of infection by Rhizobium. Any impact of $\mathrm{Al}$ on root hairs would indirectly limit $\mathrm{N}$ fixation capacity of clover. Wood et al. (1984) found that nodulation was inhibited in white clover cv. Huia at $\mathrm{Al}$ concentrations that still supported some root hair growth but root hair numbers were not recorded. De Carvalho et al. (1982) found that root infection and/or nodule initiation in Stylosanthes were more sensitive to $\mathrm{Al}$ than subsequent nodule development. If nodulation 
is more sensitive than root hair development, there may be an additional physiological effect of Al on the nodulation process, as well as the physical effect caused by a decrease in sites for rhizobium infection. One of the suggested modes of action of $\mathrm{Al}$ is to induce cell wall rigidity, with $\mathrm{Al}$ replacing $\mathrm{Ca}$ and $\mathrm{Mg}$ ions in the actin network (Grabski \& Schindler 1995) and increasing the tension in the cell membrane. This rigidity may, physically or biochemically, prevent the infection thread entering the hair, but definitive proof of this is still needed.

\section{Acknowledgements}

J. Waller for statistical analysis, D. Schwalger for technical assistance; financial support from the Foundation of Research, Science and Technology.

\section{References}

Blamey, F.P.C.; Edmeades, D.C.; Asher, C.J.; Edwards, D.G.; Wheeler, D.M. 1991. Evaluation of solution culture techniques for studying aluminium toxicity in plants. pp. 905-912. In: Wright, R.D. et al. (eds). Plant-Soil Interactions at Low $\mathrm{pH}$. Kluwer Academic Publishers, Dordrecht, The Netherlands.

Caradus, J.R. 1979. Selection for root hair length in white clover (Trifolium repens L). Euphytica 28: 489-494

Care, D. 1995. The effect of aluminium concentration on root hairs in white clover (Trifolium repens $\mathrm{L}$ ). Plant and Soil 171: 159-162.

Carver, B.F.; Ownby, J.D. 1995. Acid tolerance in wheat. Advances in Agronomy 54: 117-164.

de Carvalho, M.M.; Edwards, D.G.; Asher, C.J.; Andrews, C.S. 1982. Effects of aluminium on nodulation of two Stylosanthes species grown in nutrient solution. Plant and Soil 64: 141-153

During, D. 1972. Fertilisers and soils in New Zealand Farming. N.Z. Department of Agriculture Bulletin No. 409. Government Printer, Wellington.

Edmeades, D.C.; Wheeler, D.M.; Clinton, O.E. 1985. The chemical composition and ionic strength of soil solutions from New Zealand topsoils. Australian Journal of Soil Research 23: 151-165.

Grabski, S.; Schindler, M. 1995. Aluminium induces rigor with the actin network of soybean cells. Plant Physiology 108: 897-901.

Hofer, R.M. 1991. Root Hairs. pp. 129-142. In: Waisel, Y.; Eshel, A. (eds). Plant roots; the hidden half. Marcell Dekker Inc., New York.

Itoh, S.; Barber, S.A. 1983. Phosphorus uptake of six plant species as related to root hairs. Agronomy Journal 76: 477-481.

Jones, D.L.; Shaff, J.E.; Kochian, L.V. 1995. Role of calcium and other ions in directing root hair tip growth in Limnobium stoloniferum. I. Inhibition of tip growth by aluminium. Planta 197(4): 672-680.

Motomizu, S.; Toshiaki, W.; Kyoji, T. 1983. Spectrophotometric determination of phosphate in river waters with molybdate and malachite green. The Analyst 108: 361-367.

Nutman, P.S. 1959. Some observations on root hair infection by nodule bacteria. Journal of Experimental Botany 10: 250-263

Parfitt, R.; McDonald, W. 1992. Soil acidity map of New Zealand using GIS. Soil News 40: 59-64.

Wheeler, D.M.; Edmeades, D.C.; Christie, R.A. 1992. Effect of aluminium on plant chemical concentrations in some temperate grasses grown in solution culture at low ionic strength. Journal of Plant Nutrition 15(4): 387-402

Wheeler, D.M.; Edmeades, D.C. 1995. Effects of depth and lime or phosphorus fertiliser applications on the soil solution chemistry of some New Zealand pastoral soils. Australian Journal Soil Research 33: 461-476.

Wolt, J.D. 1994. Soil solution chemistry: Applications to Environmental Science and Agriculture. John Wiley and Sons, Inc. New York.

Wood, M.; Cooper, J.E.; Holding, A.J. 1984. Aluminium toxicity and nodulation of Trifolium repens. Plant and Soil 78: 381-391. 